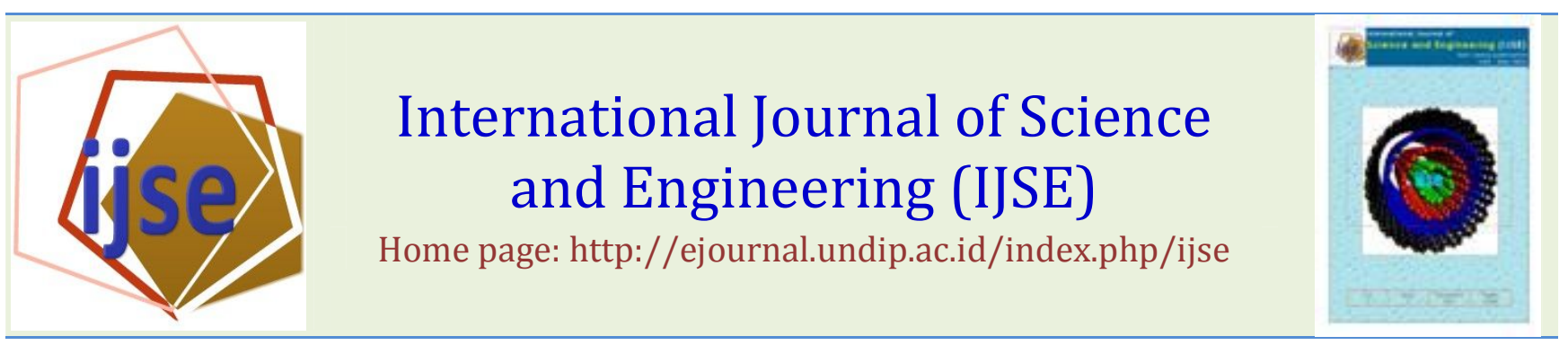

\title{
Pelletisation Behavior of Fluxed Iron Ore Pellets of Varying Basicities Made with Waste Fines
}

\author{
Alok Sarkar ${ }^{1}$, A.K. Mandal ${ }^{2}$ \& O. P. Sinha ${ }^{3}$ \\ Department of Metallurgical Engineering, IIT (BHU), Varanasi-221005(India) \\ e-mail: ${ }^{1}$ alok.besusmet@gmail.com; ${ }^{2}$ arup9180@yahoo.co.in; ${ }^{3}$ opsinha.met@iitbhu.ac.in \\ ${ }^{2}$ corresponding author
}

\begin{abstract}
The present study deals with the utilization of fines generated from comminution process (crushing, grinding and screening) of the Run of Mines into value added products i.e. fluxed iron ore pellets. The study comprises to understand the physical and mechanical behavior of five distinguished chemical compositions of green and dried iron ore pellets with respect to a typical Mini Blast furnace (MBF) burden data and furnace operating parameter. The maximum basicity of pellets was calculated 2.37 to make slag neutral when blast furnace runs at $100 \%$ high ash coke (avg. ash content $=29 \%$ ). The crushing strength and drop number of various green pellets were measured. Green Crushing Strength was decreased with increasing lime fines. The addition of lime fines as a burnt lime, which has acicular structure creates less plasticity and brittle like fracture occurred. Due to formation of hard $\mathrm{CaCO}_{3}$ layer on the surface, after increasing lime contain crushing strength was increased in the air and oven dry pellets with respect to acid pellet (0\% lime fines addition).
\end{abstract}

Key Words - Agglomeration, Crushing strength, Burnt Lime, Fluxed Pellets, Waste Fines

Submission: June 14, $2013 \quad$ Corrected : July 13, $2013 \quad$ Accepted: July 15, 2013

Doi: $10.12777 /$ ijse.5.2.9-14

[How to cite this article: Sarkar, A., Mandal, A.K., and Sinha, O.P. (2013) Pelletisation Behavior of Fluxed Iron Ore Pellets of Varying Basicities Made with Waste Fines. International Journal of Science and Engineering, 5(2),9-14. Doi: 10.12777/ijse.5.2.9-14]

\section{INTRODUCTION}

For the production of suitable sized feed materials $(-40 \mathrm{~mm}$ to $+15 \mathrm{~mm})$ for Blast Furnace, during comminution process (crushing, grinding and screening) of the Run of Mines (ROM) generates a lot of fines $(-15 \mathrm{~mm})$ almost $50 \%$ of the total output of sized iron ore and almost $50 \%$ of total lime made (Mandal et al., 2012; IMY, 2011; UKMY, 2006).

India is the $4^{\text {th }}$ largest steel producer in the world. India produced 76.715 million tons of crude steel in the year of 2012 where world steel production was 1510.223 million tons against 72.7 million tons of steel in the year of 2011 where world produced 1490.060 million tons of steel (Mandal et al., 2012; C.S. Production, 2012). It is being expected that Indian steel production will grow 10\% during 2010-2013 (Mandal et al., 2012). World Blast Furnace Iron (BFI) Production in the year of 2012 was total 1100.674 million tons by 38 countries in which India produced 42.258 million tons occupying also 4 th position in the world (BFI Production, 2012), whereas World Direct Reduced Iron (DRI) Production in the year of 2012 was total 55.361 million tons by 11 countries in which India produced 19.799 million tons occupying $1^{\text {st }}$ position (DRI Production, 2012).

For making Blast furnace feed material from ROM ore, materials are subjected to Mineral Beneficiation Operation (Crushing, Grinding, Sizing, Washing etc.). According to Indian Bureau Of Mines, Nagpur, the total output of 208 million tones of ROM in which, lump iron ore constituted 82.2 million tones or about 39.5\%, fines 125.1 million tones or about $60.2 \%$ and concentrates 0.7 million tones or about $0.3 \%$ of the total output of iron ore lumps (IMY, 2011), $20 \%$ of total coal mined and $22.5 \%$ quarry fines of lime stone (Quarry fines are those fines generated by processes related to blasting, processing, handling and transportation ) i.e. almost $50 \%$ of total lime made (UKMY, 2006). The particles, smaller than $3 \mathrm{~mm}$ size, are generated commonly termed as "Waste Fines". These fines are partially utilized in the processes like Pellet Making, Power Plant, and Desulphurization respectively. The disposal of these solid waste fines increases the cost; render material loss and 
posses many environmental issues. The conversion of solid waste fines into value added products for use is the policy of the day.

Critical analysis of the reported literature indicates that problems of lump lime charging in the BOF like high melting point and slow dissolution could be overcome by the development of suitable lime-fluxed iron oxide agglomerates viz. sinter, briquette, or pellet. Additionally, preparation of such agglomerates may provide an opportunity toward proper utilization of iron ore fines and limestone fines simultaneously (Pal et al., 2011)

In conventional method, Lime Stone and Dolomite in bulk are being used as flux inside the blast furnace. The main problem of adding these as a flux is 'alkali loading' inside the furnace. The alkali cycle inside the Blast Furnace is maintained in between $900^{\circ} \mathrm{C}-1100^{\circ} \mathrm{C}$ (Biswas, 1981). This problem could be minimized by using hardened fluxed iron ore pellets because during hardening $\left(>1100^{\circ} \mathrm{C}\right)$ operation of the fluxed pellets, alkali $\left(\mathrm{Na}_{2} \mathrm{O}, \mathrm{K}_{2} \mathrm{O}\right)$ got evaporated. Since the last three decades, fluxed iron ore pellets have been slowly taking over the load of acid pellets as the primary burden around the world. In fluxed pellets, limestone and dolomite are added to the magnetite or hematite concentrate, which already contains silica as a gangue. One of the primary strength forming mechanisms in iron ore pellets is the formation of liquid bridges between the iron oxide particles at high temperature. Adding of lime to iron ore pellets changes the chemistry of these liquid bridges from iron silicates to iron calcium silicates (Firth et al., 2008).

It has been proven theoretically and experimentally that the use of $10 \%-30 \%$ DRI in blast furnace along with iron ore or sinter results in lowering coke rate and higher productivity (Gupta, 1999). As the amount of coke required for melting is three times less than the amount of coke required for smelting (Schriefer, 1995).

A valuable observation has been made by Steel Authority of India Ltd. that the use of sponge iron in BFs may not pick up very strongly at present, but, in the medium term, it is expected to change in favour of charging sponge iron in blast furnaces (EBR, 2010). In addition, the use of DRI also improves the production rate, variation in the hot metal composition and decreases the amount of flux required for fluxing (Kaushik and Fruehan, 2006a; Kunitomo et al., 2006; Sakamoto et al., 1988; Tang M., 1999). It has been reported that the use of DRI in blast furnace not only reduces energy consumption in the existing blast furnace iron making process but also reduces the energy consumption related to Carbon Dioxide emission in the total hot metal production processes, including the partial reduction process (Nogami et al., 2006; Kaushik and Fruehan, 2006a; Kaushik, and Fruehan., 2006b).

The present study deals with the making of fluxed pellets for gainful utilization of these materials to get fluxed iron ore pellets as Blast Furnace feed material comparing with the typical burden data when the furnace was running at $100 \%$ lump iron ore (average of three months) of an Indian MBF. Lime fines were added with the required proportion of iron ore fines to get the different basicity in contrast with the parent burden used when furnace runs at different composition and proportion (blending) of coke used. It was tested for its physical and mechanical properties of different basicity pellets.

\section{EXPERIMENTAL}

\section{A. Raw materials}

In the present investigation, we used iron ore from Orissa (India) and limestone Rajasthan mines (India). Calcined (burnt) lime and iron ore samples were ground separately in a laboratory ball mill of $5 \mathrm{~kg}$ capacity and all samples were screened through BS-72 mesh $(0.2 \mathrm{~mm})$ sieve separately.

\section{B. Characterization of Raw Materials}

Chemical Analysis of iron ore and lime stone were done with weight method. Results are shown in Table I.

TABLE I

CHEMICAL ANALYSIS OF IRON ORE AND LIME STONE

\begin{tabular}{|l|l|l|l|l|l|l|l|l|r|r|r|}
\hline $\begin{array}{c}\text { Raw } \\
\text { Material }\end{array}$ & $\mathrm{Fe}(\mathrm{T})$ & $\mathrm{SiO}_{2}$ & $\mathrm{Al}_{2} \mathrm{O}_{3}$ & $\mathrm{CaO}$ & $\mathrm{MgO}$ & $\mathrm{Mn}$ & $\mathrm{P}$ & $\mathrm{S}$ & $\begin{array}{r}\mathrm{Fe}_{2} \\
\mathrm{O}_{3}\end{array}$ & Alkali & LOI \\
\hline $\begin{array}{l}\text { Iron Ore } \\
\text { fines }\end{array}$ & 64 & 1.8 & 2.6 & - & 0.08 & 0.07 & 0.03 & 0.001 & - & 0.1 & 2.5 \\
\hline $\begin{array}{l}\text { Lime Stone } \\
\text { fines }\end{array}$ & - & 1.2 & 1 & 52 & 2 & - & 0.022 & & 0.5 & 0.23 & 40 \\
\hline
\end{tabular}

From the XRD analysis (On model no Rigaku D-MAX IIIB) of iron ore and lime fines it was observed that $\% \mathrm{Fe}_{2} \mathrm{O}_{3}$ in iron ore was around 95\% which indicates the iron ore was as hematite and soft in nature and also burnt lime powder used was least amount of un carbonized $\mathrm{CaCO}_{3}$ (i.e. $<5$ ) (Mandal et al., 2012).

\section{Calculation of lime addition}

For the present study we were taking in consideration of a typical Indian MBF operating data and chemical analysis (average of three months of September, October and November) to determine the maximum pellet basicity, which are given in Table II.

TABLE II

PARAMETERS OF MBF TAKING UNDER CONSIDERATION

\begin{tabular}{|l|c|c|c|c|}
\hline \multicolumn{2}{|c|}{ Coke used } & \multicolumn{2}{c|}{ H.M analysis } \\
\hline Type & Low Ash & High Ash & $\mathrm{C}$ & 4.3 \\
\hline Avg. Ash & 14 & 29 & $\mathrm{Si}$ & 2 \\
\hline $\mathrm{SiO}_{2}$ in Ash & 48 & 54 & $\mathrm{~S}$ & 0.05 \\
\hline $\begin{array}{l}\text { Coke rate (dry), } \\
\text { when } \\
\text { used in burden }\end{array}$ & 640 & 765 & $\mathrm{Pn}$ & 0.8 \\
\cline { 4 - 5 } & & & $\mathrm{Fe}$ & 0.05 \\
\hline
\end{tabular}

In the case of using in $100 \%$ low ash coke in the burden, Dry Coke Rate lies around 640kg/THM, Ash in the Low ash coke $14 \%$ and $\mathrm{SiO}_{2}$ contain in Low Ash coke ash is $48 \%$, So $\mathrm{SiO}_{2}$ input through coke and iron ore to produce 1 
ton hot metal will be $640 \times 14 \% \times 48 \%=43.008 \mathrm{~kg}$, and $1450 \times 1.8 \%=26.10 \mathrm{~kg}$ respectively. So, total $\mathrm{SiO}_{2}$ will be $43.008+26.10=69.108 \mathrm{~kg}$. But Silicon in the hot metal is $2 \%$, means $1000 \times 2 \%=20 \mathrm{~kg}$ Silicon inside the hot metal which came from $\mathrm{SiO}_{2}$ contain of the burden, that is equivalent to $(60 \times 20) / 28=42.86 \mathrm{~kg}$ of $\mathrm{SiO}_{2}$. So net $\mathrm{SiO}_{2}$, remaining in burden will be $69.108 \mathrm{~kg}-42.86 \mathrm{~kg}=26.25 \mathrm{~kg}$, which is equivalent to $\mathrm{CaO}$ requires, to neutralize the basicity to form slag chemistry inside the blast furnace neutral $\left(B_{1}=1\right)$. So lime fines are to be added in pellets will be $(56.7 \times$ $26.25) / 52=28.62 \mathrm{~kg}$. But if we consider the $\mathrm{SiO}_{2}$ inside the Lime fines also then, $\mathrm{SiO}_{2}$ content in lime fines will be $(1.2 \times$ $28.62) / 56.7=0.61 \mathrm{~kg}$. So total $\mathrm{SiO}_{2}$ input from all sources is $(26.25+0.61) \mathrm{kg}=26.86 \mathrm{~kg}$, which is equivalent to $\mathrm{CaO}$ requires to neutralize the basicity $\left(B_{1}=1\right)$. So total lime fines are to be added is $(56.7 \times 26.86) / 52=29.29 \mathrm{~kg}$ for making one ton of liquid iron. So lime fines are to be added in the pellets to neutralize the burden basicity $\left(B_{1}=1\right)=(29.29 \times$ 100) $/ 1450=2.02 \sim 2 \%$ the same way if we use $100 \%$ High Ash coke (where, Dry coke rate $=765 \mathrm{~kg}$, ash in the High Ash coke $=29 \%$ and $\mathrm{SiO}_{2}$ contain in ash $=54 \%$ ) in the burden we have to add $7.93 \% \sim 8 \%$ of lime fines. For that reason, for the present study we took the lime fines content $2 \%$ minimum and $8 \%$ maximum. But in practical purpose, except any circumstances arise, $100 \%$ Low ash or high ash coke is not used in burden. Coke is blended in required proportion. So $4 \%$ and $6 \%$ lime fines are added in the pellets. After adding lime fines pellet basicity shown in the Table III. (Iron ore rate: Iron ore and Hot metal have $64 \%$ and $93.52 \% \mathrm{Fe}$, respectively. So for making one ton of hot metal iron ore required $=[1 /\{(1 / 92.8 \%) \times 64 \% \mathrm{X} 1000\}] \times 1000 \times 1000$ $=1450 \mathrm{~kg} / \mathrm{THM}$ )

TABLE III

COMPOSITION OF GREEN PELLETS

\begin{tabular}{|c|c|c|c|c|c|}
\hline $\begin{array}{c}\text { Optimum } \\
\text { Moisture } \\
\text { Content } \\
(\%)\end{array}$ & $\begin{array}{c}\text { Iron } \\
\text { ore } \\
(\%)\end{array}$ & $\begin{array}{c}\text { Lime } \\
\text { Fddition } \\
(\%)\end{array}$ & $\begin{array}{c}\mathrm{SiO}_{2} \text { input } \\
(\%)\end{array}$ & $\begin{array}{c}\mathrm{CaO} \\
\text { input } \\
(\%)\end{array}$ & $\begin{array}{c}\text { Pellets } \\
\text { Basicity } \\
\left(\mathrm{B}_{1}\right)\end{array}$ \\
\hline 14 & 100 & 0 & 1.8 & 0 & $\approx 0$ \\
\hline 16 & 98 & 2 & 1.788 & 1.04 & 0.58 \\
\hline 17 & 96 & 4 & 1.776 & 2.08 & 1.17 \\
\hline 18 & 94 & 6 & 1.764 & 3.12 & 1.77 \\
\hline 20 & 92 & 8 & 1.752 & 4.16 & 2.37 \\
\hline
\end{tabular}

\section{Procedure}

Green pellets of around $18 \mathrm{~mm}$ size were made with by prolonged hand rolling of moistened iron ore fines of BS -72 mesh size without bentonite as per flow chart (Fig. 1). The disadvantages of unwanted impurities by using bentonite were discussed in several studies. For instance, the addition of $1 \%$ bentonite, containing $85 \% \mathrm{SiO}_{2}+\mathrm{Al}_{2} \mathrm{O}_{3}$, decreases the pellet's iron content to $0.6 \%$ (De Souza et al., 1984).

\section{E. Determination of optimum moisture content}

Optimum moisture content test were performed for iron ore pellets at different lime addition $(0 \%, 2 \%, 4 \%, 6 \%$ and $8 \%$ ) where maximum strength was analyzed (Fig. 2). Green pellets of around $18 \mathrm{~mm}$ size were made with optimum water content by prolonged hand rolling of moistened iron ore fines of BS -72 mesh size without bentonite as per flow chart (Fig. 1).

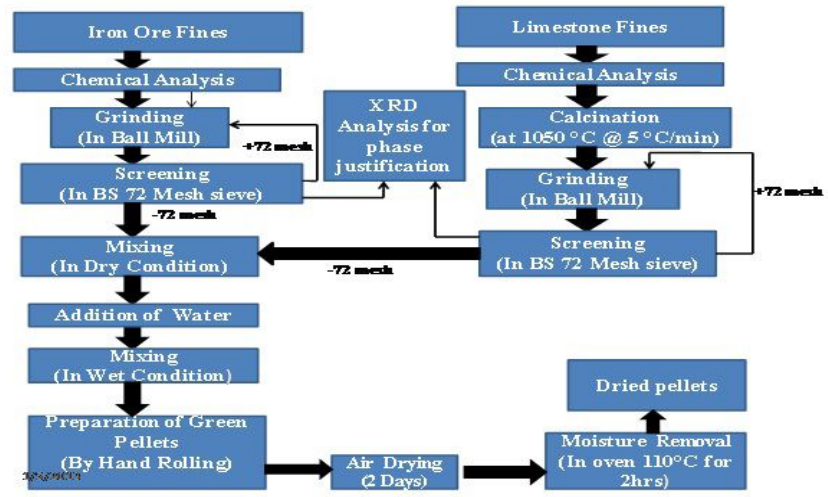

Fig. 1 Process flow chart of preparation of pellets

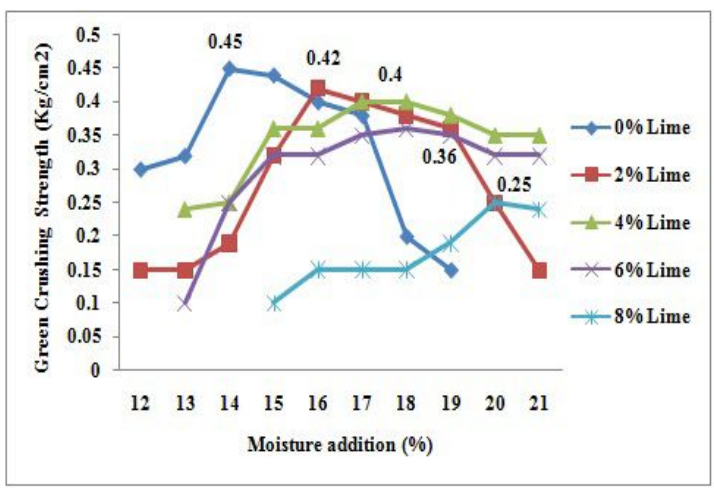

Fig. 2 crushing strength at different moisture

\section{F. Testing of Green iron ore pellets}

1) Strength: Green pellets of around $18 \mathrm{~mm}$ size were tested for crushing strength with the help of a 'Green crushing strength measurement setup' as shown in Fig. 3. Drop strength was measured by dropping the pellets at a height of $450 \mathrm{~mm}$ over a steel surface until break (Gupta, 2010). Properties of different types of green iron ore pellets were given in Table II. 


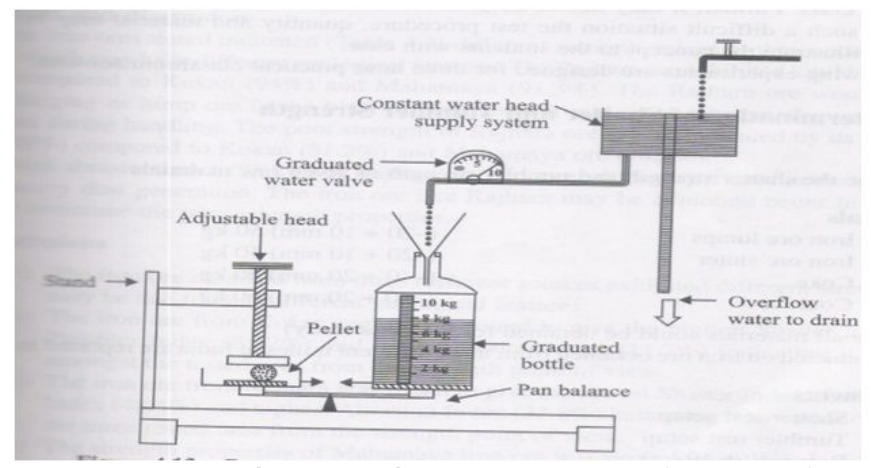

Fig. 3 Green crushing strength measurement set up (Gupta, 2010)

The green pellets were air dried for two days to get moisture free surface and sufficient strength for further treatment. Three pellets of each composition were taken out for testing purpose. Rest pellets were dried at $110^{\circ} \mathrm{C}$ for 2 hrs in an oven and similarly 3 pellets of each composition taken out for testing purpose. These oven dried pellets were then kept in desiccators for its characterization (crushing strength and microstructure). Dried pellets (air and oven dried) are subjected to compressive load in low range UTM (AGS-5kND, make SHIMADZU) for strength measurement.

TABLE II

COMPOSITION OF GREEN PELLETS

\begin{tabular}{|c|c|c|c|c|c|}
\hline \multicolumn{1}{|c|}{$\begin{array}{c}\text { Optimum } \\
\text { Moisture } \\
\begin{array}{c}\text { Content } \\
(\%)\end{array}\end{array}$} & $\begin{array}{c}\text { Iron } \\
\text { ore } \\
(\%)\end{array}$ & $\begin{array}{c}\text { Lime Fines } \\
\text { Addition } \\
(\%)\end{array}$ & $\begin{array}{c}\mathrm{SiO}_{2} \\
\text { input } \\
(\%)\end{array}$ & $\begin{array}{c}\mathrm{CaO} \\
\text { input } \\
(\%)\end{array}$ & $\begin{array}{c}\text { Pellets } \\
\text { Basicity } \\
\left(\mathrm{B}_{1}\right)\end{array}$ \\
\hline 14 & 100 & 0 & 1.8 & 0 & $\approx 0$ \\
\hline 16 & 98 & 2 & 1.788 & 1.04 & 0.58 \\
\hline 17 & 96 & 4 & 1.776 & 2.08 & 1.17 \\
\hline 18 & 94 & 6 & 1.764 & 3.12 & 1.77 \\
\hline 20 & 92 & 8 & 1.752 & 4.16 & 2.37 \\
\hline
\end{tabular}

2) Microstructure: Dried pellets are subjected under SEM (FEI Quanta-200FEG) at $20 \mathrm{kv}$ on scan rate $10 \mu$ s with ETD detector, to observe the outer surface of the pellets of higher basicity pellet for determining the lime fines distribution and porosities as well as formation of any $\mathrm{CaCO}_{3}$ layer over the surface.

A. Characteristics of Raw Materials

Qualities of burden materials affect the economy, output, and efficiency of the furnace operation. The chemical analysis of iron ores and lime stone under investigation were listed in Table I. The value of iron content in the iron ore was $64 \%$ and $52 \% \mathrm{CaO}$ in Lime Stone. Data for the mineralogical composition indicated that the gangue materials in the iron ore mainly alumina and silica with a negligible amount of $\mathrm{MgO}, \mathrm{Mn}, \mathrm{P}, \mathrm{S}$ and alkali.

The XRD analysis of iron ore (not seen) reveals that \% $\mathrm{Fe}_{2} \mathrm{O}_{3}$ in iron ore was around 95\%. It means that iron ore was as hematite and soft in nature. Similarly XRD analysis of lime fines was indicated the different phases present in burnt lime. $\mathrm{CaCO}_{3}$ was observed very less in quantity (i.e. $<5)$. It could be concluded that the burnt lime has only $\mathrm{CaO}$ (Mandal et al., 2012).

\section{B. Physical and Mechanical Properties}

1) Fracture behavior of green pellets: During water addition for making green pellets with burnt lime, huge steam formed due to exothermic reaction of burnt lime with water. The making of pellets became difficult due to hot steam exit from the pellets. During crushing strength measurement of green pellets, it was observed that in acid pellets, crack initiates and propagate slowly until fracture. But increasing lime content it was observed that crack initiates and propagate instantly and fracture occurred without warning (Fig. 5). It means that increasing lime content decreases the plasticity and fractured occurred like brittle in nature. The SEM micrograph of lime fines particle reveals that the acicular/ needle like structure of the lime fines particles, (Fig 4) which lowers the plasticity inside the pellets and responsible for brittle like fracture. In the case of burnt lime added pellets, free lime particles were observed on the surface of pellets (Fig. 5 and 6).

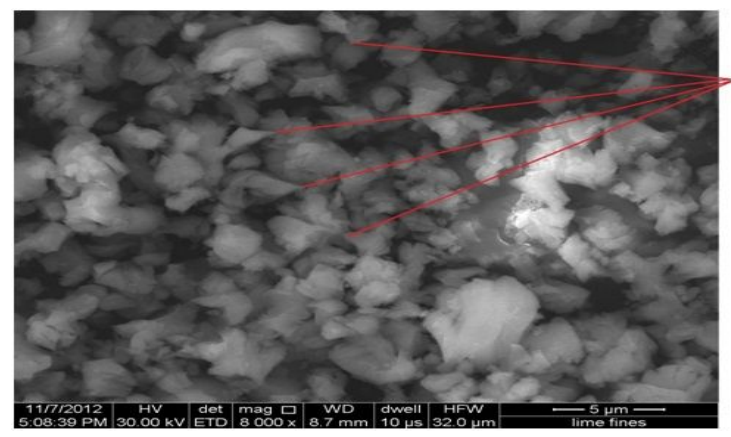

Fig 4 SEM micrograph of Lime fines

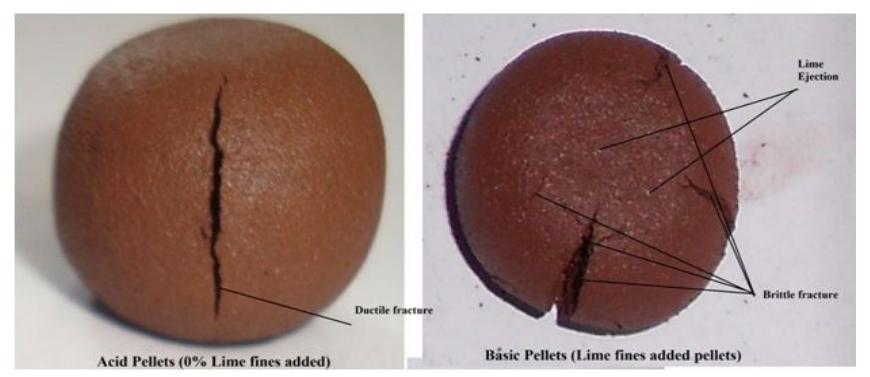

Fig 5 Fracture behavior and lime ejection in green iron ore pellets 


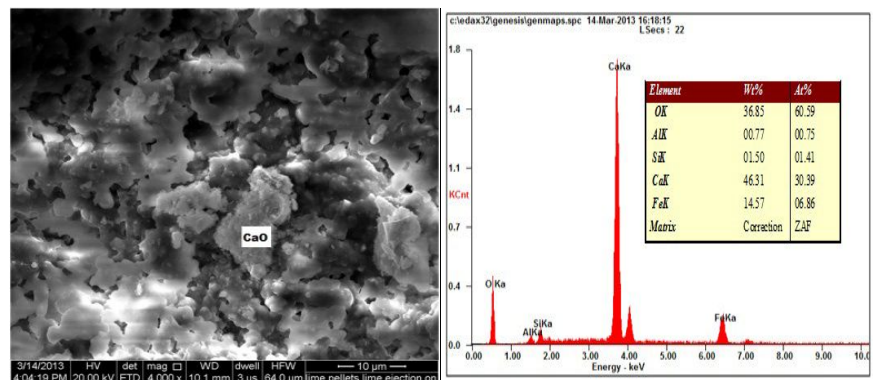

Fig 6 SEM and EDAX analysis of high basicity pellets of outer surfaces (lime ejection)

2) Strength: From the result it was observed that the green crushing strength as well as drop number of pellets was decreased with increasing lime content because of decreasing its plasticity. These decreasing trends also reported by previous authors (Umadevi et al, 2011). But increasing lime content, the calcium hydroxide of the pellet reacts with environmental $\mathrm{CO}_{2}$ and formed hard $\mathrm{CaCO}_{3}$ (Fig. 7 ), which increased its content on the surface of the green pellet which enhanced the air dried crushing strength (Patil, et al, 1980). For that reason whether increasing lime content Green Crushing strength was decreased on the other hand it was increased for air dried pellets (Fig. 8). The crushing strength of air dried, oven dried samples were increased respectively (Fig. 8).

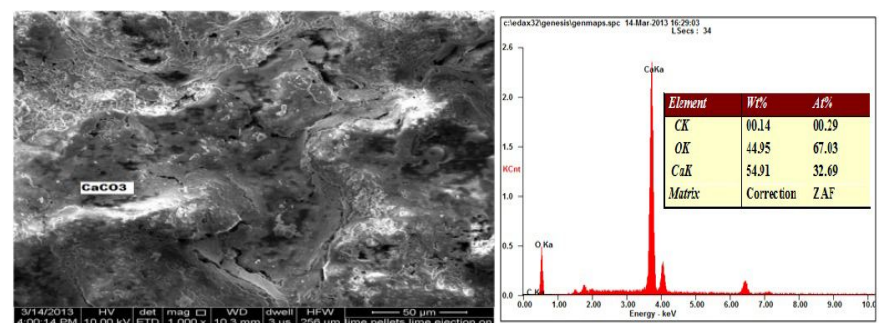

Fig 7 Formation of $\mathrm{CaCO}_{3}$ over the surface responsible for increasing green crushing strength of high basic pellets

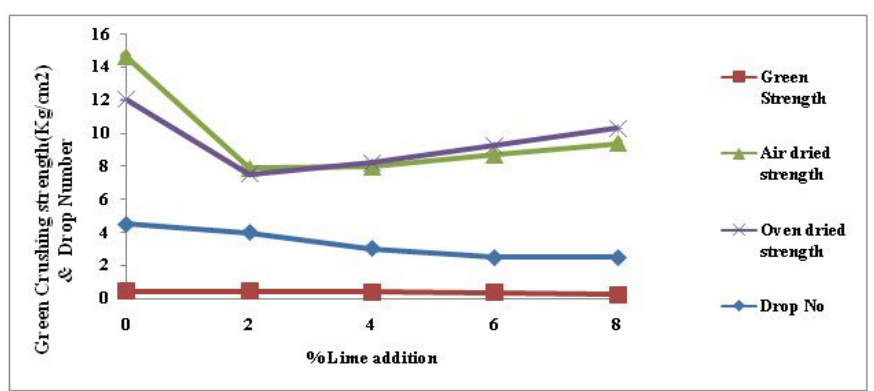

Fig 8 Strength variation of green pellets with increasing lime content

\section{CONCLUSION}

Following conclusions were drawn with reference to the Blast Furnace burden.

Huge amount of lime and iron ore fines generated from mines can be utilized for making fluxed pellets which can minimize the problem of use lime stone concentrate inside the Blast Furnace
In a typical Blast Furnace burden consideration, we can calculate the maximum pellets basicity (2.37), to produced neutral slag is as low as only $8 \%$ addition(maximum) of lime fines in the pellets when use $100 \%$ high ash coke.

Increasing lime content decreased green crushing strength as compared to acid pellets due to burnt lime lime fines have the acicular/ needle like structure which retards the plasticity inside the pellets so after applying load over the pellets sudden brittle like fracture occurred without any prior deformation.

During water addition for making green pellets with burnt lime, huge steam formed inside the pellets for exothermic reaction of burnt lime with water, which creates pressure inside the pellets. When these steams tried to exit, creates pores over the surfaces which were the crack initiation area for producing crack.

But at the other hand, $\mathrm{CaO}$ is reacted with moisture content of pellets and formed $\mathrm{Ca}(\mathrm{OH})_{2}$. These $\mathrm{Ca}(\mathrm{OH})_{2}$, after further reaction with atmospheric $\mathrm{CO}_{2}$ produced hard layer of $\mathrm{CaCO}_{3}$ over the outer surface the pellets, which was responsible for further increase in strength. So increasing lime content crushing strength was also increased.

\section{REFERENCES:}

[1]. BFI Production, (2012); http://www.worldsteel.org/statistics/BFIprodu ction.html

[2]. Biswas, A. K. (1981). Principles of Blast Furnace Iron Making, 1 st edition, SBA publication, Kolkata, ISBN 0-949917-08-7: pp 496.

[3]. Crude Steel Production, (2012); http://www.worldsteel.org/statistics/ crude-steel-production.html

[4]. De Souza, R.P., De Mendonca, C.F., Kater, T., (1984). Production of acid iron ore pellet for direct reduction using an organic binder. Mining Eng. Magn. 36(10): 1437-1441

[5]. DRI Production, (2012); http://www.worldsteel.org/statistics/DRIprodu ction.html.

[6]. EBR, (2010). A report on the environmental benefits of recycling- a critical review of the data for steel'. Steel Times International. Redhill. $\mathrm{UK}$;

http://www.bir.org/assets/PressCuttings/CoverageSteelTimes.pdf.

[7]. Firth, A.R., Garden, J.F., Douglas, J.D, (2008). Phase Equilibria and Slag Formation in the Magnetite Core of Fluxed Iron Ore Pellets. ISIJ International.48(11): 1485-1492;

http://dx.doi.org/10.2355/isijinternation al .48.1485.

[8]. Gupta, R.C., (1999). Alternative routes of Iron and Steel making (ICARISM-99). Proceeding on International Conference on The AUSIMM and CSIR Minerals, Waterford, pp 59

[9]. Gupta, R.C., (2010). Theory and Laboratory Experiments in Ferrous Metallurgy. PHI Learning. New Delhi: ISBN 978-81-203-3924-8: pp 77.

[10]. India Minerals Yearbook, (2011). (Part- II),50th Edition. iron ore,(advance release),government of India, ministry of mines, Indian Bureau of Mines, Nagpur ; http://ibm.nic.in /imyb\%202011_iron\%20ore.pdf

[11]. Kaushik, P. Fruehan, R.J., (2006a). Mixed burden softening and melting phenomena in blast furnace operation. AISTech proceedings, Vol. 1: pp 319-332; ISBN: 978-1-886362-85-7

[12]. Kaushik, P., Fruehan, R.J., (2006b). Behaviour of DRI and HBI in the upper blast furnace shaft: Evoluation of morphological structure of Iron. AISTech Proceedings, Vol 1: pp 51-59

[13]. Kunitomo, K., Takamoto, Y., Fujiwara, Y., Onuma, T., (2006). Blast furnace iron making process using pre-reduced iron ore. Nippon Steel Technical Report, No. 94, pp 133-138, UDC 669. 162. 26: 622.341. 118; http://dc307.4shared.com/doc/wmc2I2AH/preview .html. 
[14]. Mandal, A.K., Sarkar, A., Sinha, O.P., (2012). Conversion of solid waste fines of comminution process into feeding material of Blast Furnace grade iron ore pellets. SGAT Bulletin, 139(2): 95-113; ISSN 09722173.

[15]. Nogami, H., Yagi, J., Kitamura, S., Austin, P. R., (2006). Analysis on material and energy balances of Iron Making systems on Blast furnace Operations with Metallic Charging, Top gas recycling and natural gas injection. ISIJ International, 46(12): 1759-1766; http://dx.doi.org/10.2355/isijinternational.46.1759

[16]. Pal, J., Ghorai, S., Singh, D. P., Goswami, M. C, Bandyopadhyay, D. \& Ghosh, D., (2011). Dissolution Characteristics of CO2-Treated Fluxed Pellets in Hot Metal Bath. Mineral Processing and Extractive Metallurgy Review. 32(4): 229-246; DOI:10.1080/08827508.2010.53071

[17]. Patil, J. B., Kakkar, N. K., Srinivasan, T. M., Dharanipalan, S., Patel, B. B., Nayak, N. M., (1980). Production of cold bonded pellets. Transaction of the IIM, 33(5): 382-390
[18]. Sakamoto, N., Noda, H., Saito, Y.H., Miyashita, T., (1988). Fundamentals investigation of new iron ore agglomerates and evaluation of their properties for the blast furnace. Transactions ISIJ, 28: 621-627;

https://www.jstage.jst.go.jp/article/isijinternational1966/28/8/28_ 8_619/_pdf.

[19]. Schriefer, J., (1995). Alternative irons for Electric and Blast Furnaces. New Steel. 11(2), pp 16-19.

[20]. Tang Ma, (1999). Injection of fluxed in to the blast furnace via tuyers for optimizing slag formation, ISIJ International. 39 (7): 697-704; http://dx.doi.org/10.2355/isijinternational.39.697

[21]. UK Minerals Yearbook, (2006). lime stone; www.mineralsuk.com/britmin/ ukmy2006.pdf .

[22]. Umadevi, T., Kumar, P., Lobo, N. F., Prabhu, M., Mahapatra, P.C., Ranjan, M., (2011). Influence of Pellet Basicity (CaO/SiO2) on Iron Ore Pellet Properties and Microstructure. ISIJ International, 51(1): 14-20; http://dx.doi.org/10.2355/isijinternatio nal.51.14 